\title{
Academic, Financial and Administrative Issues of Online Teaching During Corona Pandemic: The Scenario of Private Universities in Bangladesh
}

\author{
Zulfiqar Hasan $P h D$ \\ Associate Professor (Finance) \\ Dept. of Business Administration \\ Bangladesh Islami University, Dhaka, Bangladesh \\ E-mail: hasanzulfiqar@yahoo.co.uk \\ K. M. Anwarul Islam PhD Candidate \\ Faculty of Business and Accountancy \\ University of Selangor, Malaysia \\ E-mail: ai4I9bankingdu@gmail.com
}

\begin{abstract}
Regarding financial and administrative issues involved in online teaching, the study focuses on the views of the teachers of private universities in conducting online classes during the corona pandemic in Bangladesh. Based on primary data collected from teachers of 22 private universities selected randomly, study finds some reasons for online classes like financial needs and obligations of the university to pay the salaries and other allowances by collecting tuition fees from the students, to save the academic year of the students, to follow the directives of the UGC and Government, etc. The study also finds some significant differences in the uses of technology, internet, and equipment by the teachers before and during the corona pandemic. Online teaching has significant effects on teachers' training, student's punctuality in attending classes, interactions between teachers \& students. It also helps authority in monitoring the classes. Finally, the study recommends some policy guidelines for the University Owners \& authorities, Government, UGC, and the faculty members as well.
\end{abstract}

Keywords: Private University, Online Teaching, Financial Demand, Corona Pandemic.

JEL Classification: A23, M4I.

\section{Introduction}

In Bangladesh, there are I05 listed private universities (Akter, 20I7). Since March I7, 2020 government asked to stop academic activities of the educational institutions of the country for the safety of the stakeholders. From then, for their interests, some private universities have started academic activities through online teaching. Almost every higher educational institution is challenged to develop an increasing number of staff to teach online or blended modes of learning. The process needs to be rapid, cost-effective, and lead directly to practical outcomes (Gregory \& Salmon 2013). But there is a big debacle about these teaching methods as it is a new practice in the university education of Bangladesh. Universities claimed that the online teaching method rescued the academic activities of the students and the universities. University grants commission also permitted to conduct the classes through an online platform. The University Grants Commission (UGC) has permitted private universities to hold the online exam to complete the running semester which has already completed $70 \%$ of the syllabus with at least $60 \%$ of students being present (DhakaTribune, 2020). The UGC chairman said: "Future may have many uncertainties, but difficult times demand a quick and appropriate decision. We must be optimistic that we can reinvent work and engage the students effectively and constructively." To conduct classes online, 24-hour internet facilities are demanded by teachers and students. Khan (2020) mentioned that the internet is keeping the world somehow walking in the darkest hours of the Covid-I9 pandemic. And mobile telephony is the tool that is keeping Bangladesh limping. On the other hand, due to the suspension of on-campus classes, private universities facing problem to collect tuition fees from the students. Tuition fees are the main source of revenue for private universities in Bangladesh. In a statement, the Association of Private Universities of Bangladesh said private universities have not faced such a financial crisis since 1992 (Jasim, 2020). 
As online teaching is a new issue in the higher education of Bangladesh, only a few works have been done. This article intends to find out the causes and effects of the online teaching of the private universities' education systems. Teachers' views are reflected mainly through this article.

\section{Research Objectives}

The study aims to -

- Find out the causes of online teaching regarding financial, academic and administrative issues

- Chalk out the effects of online teaching

- Find out the problems of conducting online teaching and

- Recommend policy to conduct online teaching effectively.

\section{Research Methodology}

This study attempts to describe the effects of online teaching in the private university sectors of Bangladesh during the corona pandemic. This is mainly a primary data-based empirical research. Data are collected by using a random sample model. If a sample is selected according to the rules of probability, it is called a random sample (Islam, 2015). A prescribed questionnaire is used to find out the effects of online teaching systems. The study uses a simple random sampling method. A total of I32 university teachers in different capacities are selected randomly from 22 private universities in different places of the country. Places indicate private universities situated in metropolitan cities and district levels. The reasons behind this area selection are the availability of internet and electricity services. Data were collected from the last week of March 2020 to the $3^{\text {rd }}$ week of May 2020 by using a prescribed questionnaire. Likert scale 5.0 is used in the study. Test of hypotheses, ANOVA, correlations, etc. are used to analyze the results.

\section{Hypotheses of the Research}

Following null hypotheses are designed:

HoI: Maximum teachers were well trained on online teaching before corona pandemic

H.2: Teachers were well equipped for online teaching before corona pandemic

Ho3: Most private universities provided financial support of internet data cost to the teachers

H.4: Maximum universities arranged training program for teachers regarding online teaching

Ho5: Student participation and attendances are not more in online classes than in regular on-campus classes

\section{Analysis and Findings}

\section{I Distribution of the Respondents (Teachers)}

Total 132 numbers of teachers from various capacities like Professor (8), Associate Professor (I9), Assistant Professor (44), Senior Lecturer (I4), and Lecturer (47) have been selected randomly from the metropolitan area and district level private universities of Bangladesh. Teachers are selected from both the general stream (86 respondents) and the science stream (46 respondents). Combined frequency table of Teachers, Location, and taught areas are given below:

Table I. Distributions of Teachers by Location of the University and Academic Discipline

\begin{tabular}{|c|c|c|c|c|c|c|c|c|c|c|}
\hline \multicolumn{11}{|c|}{ Location of the University \& Academic Discipline } \\
\hline \multirow[t]{2}{*}{$\begin{array}{l}\text { Rank of } \\
\text { Teachers }\end{array}$} & \multicolumn{2}{|c|}{ Metropolitan City } & \multicolumn{2}{|c|}{$\begin{array}{c}\text { District/District } \\
\text { City }\end{array}$} & \multicolumn{2}{|c|}{ Others } & \multicolumn{2}{|c|}{ Total } & \multirow{2}{*}{ تేّ } & \multirow{2}{*}{ 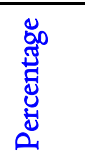 } \\
\hline & Science & General & Science & General & Science & General & Science & General & & \\
\hline Professor & 0 & 5 & 0 & 3 & 0 & 0 & 0 & 8 & 8 & 6.1 \\
\hline $\begin{array}{l}\text { Associate } \\
\text { Professor }\end{array}$ & 2 & 9 & I & 5 & I & I & 4 & I5 & 19 & $\mathrm{I} 4.4$ \\
\hline $\begin{array}{l}\text { Assistant } \\
\text { Professor }\end{array}$ & 17 & 17 & 5 & 5 & 0 & 0 & 22 & 22 & 44 & 33.3 \\
\hline $\begin{array}{l}\text { Senior } \\
\text { Lecturer }\end{array}$ & 3 & 5 & $\mathrm{I}$ & 5 & 0 & 0 & 4 & 10 & I4 & 10.6 \\
\hline Lecturer & $\mathrm{II}$ & 19 & 3 & 10 & 2 & 2 & 16 & $3 \mathrm{I}$ & 47 & 35.6 \\
\hline Total & 33 & 55 & I0 & 28 & 3 & 3 & 46 & 86 & I32 & $100 \%$ \\
\hline
\end{tabular}


Among the respondents, Lecturers (Lecturer \& Senior Lecturer) are 47.8\%, Assistant Professors are 32.6\%. Responses of Professor (6.1\%) and Associate Professor (I4.4\%) are not at a satisfactory level in this survey. This is basically for the existence of a poor number of senior teachers in private universities in Bangladesh. The study has chosen 23 private universities randomly from different parts of the country. Table-I shows that the maximum respondents are from metropolitan cities of Bangladesh. Some universities are situated at district levels. The number of respondents from universities situated in rural areas is very poor (6) which are shown in Table-I.O.

\subsection{Causes of Online Teaching}

The study classifies the reasons that are in three categories: Academic Issues, Financial Issues, and Administrative Issues.

\subsection{Academic Issues}

- Resuming of Academic Activities

- The demand for Students and Guardians

- Improving Interactions of Teachers and Students

\subsubsection{Financial Issues}

- Financial Demands \& Tuition Fees Collections

- Paying Salary, allowances, dues and

- Managing operating costs

\subsubsection{Administrative Issues}

- Directives of UGC to conduct online classes and examinations

- Class monitoring becomes easier by the authority

- Reducing 'No work No pay' Threat

- Work from Home Opportunity

\subsubsection{Teachers' View on Online Classes During Corona Pandemic}

Table 2 presents the teachers' view to find out the reasons for online classes by private universities regarding academic, financial and administrative issues.

Table 2. Reasons for Conducting Online Classes

\begin{tabular}{|c|c|c|c|c|c|c|c|c|}
\hline & & 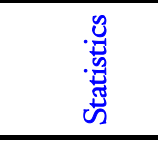 & 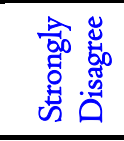 & 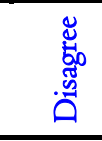 & 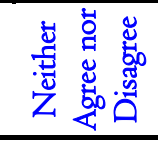 & 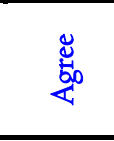 & 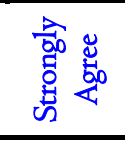 & సีّ \\
\hline \multirow{2}{*}{ OI } & \multirow{2}{*}{$\begin{array}{l}\text { Class monitoring becomes easier by the } \\
\text { authority }\end{array}$} & Count & 7 & $\mathrm{I} 2$ & 30 & 34 & 49 & 132 \\
\hline & & $\%$ of Total & $5.3 \%$ & $9.1 \%$ & $22.7 \%$ & $25.8 \%$ & $37.1 \%$ & $100 \%$ \\
\hline \multirow{2}{*}{02} & \multirow{2}{*}{ The demand for Students and Guardians } & Count & 3 & 6 & 26 & 42 & 55 & 132 \\
\hline & & $\%$ of Total & $2.3 \%$ & $4.5 \%$ & $19.7 \%$ & $31.8 \%$ & $41.7 \%$ & I00\% \\
\hline \multirow{2}{*}{03} & \multirow{2}{*}{\multicolumn{2}{|c|}{$\begin{array}{l}\begin{array}{l}\text { Improving Interactions of } \\
\text { Students }\end{array} \\
\text { Teachers and Count } \\
\% \text { of Total }\end{array}$}} & 9 & 4 & I5 & 33 & $7 \mathrm{I}$ & 132 \\
\hline & & & $6.8 \%$ & $3.0 \%$ & $\mathrm{II} .4 \%$ & $25.0 \%$ & $53.8 \%$ & $100 \%$ \\
\hline \multirow{2}{*}{04} & \multirow{2}{*}{ Financial Demands \& Tuition Fees Collections } & Count & I & 7 & I0 & 39 & 75 & 132 \\
\hline & & $\%$ of Total & $0.8 \%$ & $5.3 \%$ & $7.6 \%$ & $29.5 \%$ & $56.8 \%$ & $100 \%$ \\
\hline \multirow{2}{*}{05} & \multirow{2}{*}{\multicolumn{2}{|c|}{$\begin{array}{l}\text { Paying Salary, allowances, dues and other Count } \\
\text { operating costs }\end{array}$}} & 5 & 2 & $\mathrm{I} 4$ & 37 & 74 & $\mathrm{I} 32$ \\
\hline & & & $3.8 \%$ & $1.5 \%$ & $10.6 \%$ & $28.0 \%$ & $56.1 \%$ & $100 \%$ \\
\hline \multirow{2}{*}{06} & \multirow{2}{*}{$\begin{array}{l}\text { Directives of UGC to conduct online classes and } \\
\text { examinations }\end{array}$} & Count & 4 & 20 & 32 & 35 & $4 \mathrm{I}$ & $\mathrm{I} 32$ \\
\hline & & $\%$ of Total & $3.0 \%$ & $15.2 \%$ & $24.2 \%$ & $26.5 \%$ & $31.1 \%$ & $100 \%$ \\
\hline \multirow{2}{*}{07} & \multirow{2}{*}{ Reducing 'No work No pay' Threat } & Count & 3 & 12 & $3 I$ & 47 & 39 & 132 \\
\hline & & $\%$ of Total & $2.3 \%$ & $9.1 \%$ & $23.5 \%$ & $35.6 \%$ & $29.5 \%$ & $100 \%$ \\
\hline \multirow{2}{*}{08} & \multirow{2}{*}{ Work from Home Opportunity } & Count & 5 & $\mathrm{I} 2$ & 29 & 28 & 58 & $\mathrm{I} 32$ \\
\hline & & $\%$ of Total & $3.8 \%$ & $9.1 \%$ & $22.0 \%$ & $21.2 \%$ & $43.9 \%$ & $100 \%$ \\
\hline
\end{tabular}

Source: Developed by authors 
The study finds that the main reasons for online teaching are to resume the academic activities of private universities in Bangladesh. Private universities strictly maintain the academic calendar. So, it was a demand from the students and their guardians to start the academic activities through online systems. Non-government universities are maintaining their operating costs from the tuition fees collected from the students. Without conducting classes and examinations, the universities cannot ask the students to pay the tuition fees. Therefore, financial demands, revenues collection, payment of the salaries of teaching, and academic staff are the biggest issues to go for online teaching. In a press release on March 24, the University Grant Commission (UGC) advised the private universities to take online classes to recoup the academic losses as a result of the suspension of academic activities during the Covid-I9 outbreak. These initiatives are highly informative to the faculty members and the students to enhance their knowledge (Gomes, 2020).

\subsection{Test of Hypotheses}

The study designed 5 null hypotheses to test based ANOVA techniques of a 5\% level of significance. Test results are:

Table 3. Test of Hypotheses: ANOVA

\begin{tabular}{|c|c|c|c|c|c|c|c|}
\hline $\mathrm{H}_{\mathrm{o}}$ & Null Hypotheses & & $\begin{array}{l}\text { Sum of } \\
\text { Squares }\end{array}$ & $\mathrm{df}$ & $\begin{array}{l}\text { Mean } \\
\text { Square }\end{array}$ & $\bar{F}$ & $\begin{array}{c}\mathrm{p}- \\
\text { value }\end{array}$ \\
\hline \multirow[t]{3}{*}{$\mathrm{H}_{\mathrm{o}} \mathrm{I}$} & \multirow{3}{*}{$\begin{array}{l}\text { Maximum Teachers were well trained on } \\
\text { online teaching before corona pandemic }\end{array}$} & Between Groups & 6.906 & 4 & 1.727 & 2.750 & \multirow[t]{3}{*}{$.03 \mathrm{I}$} \\
\hline & & Within Groups & 79.730 & 127 & .628 & & \\
\hline & & Total & 86.636 & $\mathrm{I} 3 \mathrm{I}$ & & & \\
\hline \multirow[t]{3}{*}{$\mathrm{H}_{\mathrm{o} 2}$} & \multirow{3}{*}{$\begin{array}{l}\text { Teachers were well equipped for online } \\
\text { teaching before corona pandemic }\end{array}$} & Between Groups & 12.592 & 4 & 3.148 & 2.919 & \multirow[t]{3}{*}{.024} \\
\hline & & Within Groups & $\mathrm{I} 36.953$ & $\mathrm{I} 27$ & 1.078 & & \\
\hline & & Total & $\mathrm{I} 49.545$ & I3I & & & \\
\hline \multirow[t]{3}{*}{ H.3 } & \multirow{3}{*}{$\begin{array}{l}\text { Most private universities provided financial } \\
\text { support of internet data cost to the teachers }\end{array}$} & Between Groups & $54.9 \mathrm{I} 4$ & 4 & $\mathrm{I3} .728$ & $8.55 \mathrm{I}$ & \multirow[t]{3}{*}{.000} \\
\hline & & Within Groups & 203.897 & $\mathrm{I} 27$ & 1.605 & & \\
\hline & & Total & $258.8 \mathrm{II}$ & $\mathrm{I} 3 \mathrm{I}$ & & & \\
\hline \multirow[t]{3}{*}{$\mathrm{H}_{\circ} 4$} & \multirow{3}{*}{$\begin{array}{l}\text { The maximum university arranged training } \\
\text { program for teachers regarding online } \\
\text { training }\end{array}$} & Between Groups & 55.968 & 4 & 13.992 & 9.813 & \multirow[t]{3}{*}{.000} \\
\hline & & Within Groups & I8I.093 & 127 & 1.426 & & \\
\hline & & Total & 237.061 & I3I & & & \\
\hline \multirow[t]{3}{*}{ H.5 } & \multirow{3}{*}{$\begin{array}{l}\text { Student participation and attendances are } \\
\text { not more in online classes than in regular } \\
\text { on-campus classes }\end{array}$} & Between Groups & 25.317 & 4 & 6.329 & 3.799 & \multirow[t]{3}{*}{.006} \\
\hline & & Within Groups & 211.562 & $\mathrm{I} 27$ & 1.666 & & \\
\hline & & Total & 236.879 & $\mathrm{I} 3 \mathrm{I}$ & & & \\
\hline
\end{tabular}

Source: Developed by authors

In Table 3, the results of ANOVA reject all null hypotheses as the p-value is less than a $5 \%$ level of significance. So, all alternative hypotheses under this study are accepted. So, it is inferred that maximum private university teachers are not well trained on online teaching before the corona pandemic. After the declaration of resuming the classes through online, teachers are acquainted themselves with different platform like Zoom, Google Meet, Hangouts, Google Classrooms, etc. It is also inferred that teachers were not well equipped before the corona pandemic in Bangladesh to conduct online classes. Test of hypothesis also proved that maximum private universities did not provide financial supports of internet data cost to the teachers. Even most of the universities did not arrange any training program for the teachers regarding conducting online classes. As the p-value is less than 0.05 , the null hypothesis is rejected and the alternative hypothesis is accepted. So, it is inferred that student participation and attendances are more in online classes than in regular on-campus classes during the corona pandemic situation.

\subsection{Effects of Online Teaching in Private University Sectors of Bangladesh}

The present study finds positive impacts of online teaching in various aspects. Regarding the impacts of online teaching, Verpoorten, Westera, and Specht (2012). argued that today's electronic learning environment expands opportunities to reinforce reflection by prompting learners about the content at hand and about their way to internalize it. As per the directives of the University Grants Commission of Bangladesh (UGC, 2020), private universities conducted online classes which affect positively to resume the classes. The study found class monitoring becomes easier by the authority during the corona pandemic through the online class system. It is agreed upon and strongly agreed by $63 \%$ of teachers. Only $5.3 \%$ of teachers strongly disagreed with this argument. In a circular, UGC stated that during the coronavirus situation, the salaries and allowances of all the teachers/officers/employees of the university are to be paid regularly as before (UGC, 2020). After conducting online classes, 
universities were able to request the students to pay the tuition fees and other dues. Maximum private universities have fallen danger in managing working capital. Neazy (2020) an Associate Professor and Chair at the Department of English, Stamford University Bangladesh, claimed that some of the private universities in Bangladesh have cut faculty salaries by $35-70$ percent for March. Even salaries for April and May 2020 (before Eid-ul-Fitr) are also uncertain because some university authorities are eagerly waiting for a stimulus package that is yet to be announced by the government. Due to online teaching, students paid tuition fees which helped the authority of different universities to disburse the monthly salary of the teaching and academic staff. Though Bangladesh has 100 million internet users (Daily Jugantor, 2020), but maximum teachers are not connected with WiFi or broadband internet. This online teaching forced them to avail of these services.

Table 4. Purchasing of New PCs, Laptop, Tablets, or Smart Phones by Teachers for online classes

\begin{tabular}{|c|c|c|c|c|c|c|}
\hline & $\begin{array}{l}\text { Strongly } \\
\text { Disagree }\end{array}$ & Disagree & $\begin{array}{c}\text { Neither Agree nor } \\
\text { Disagree }\end{array}$ & Agree & $\begin{array}{c}\text { Strongly } \\
\text { Agree }\end{array}$ & Total \\
\hline Percentage & $15.2 \%$ & $50.8 \%$ & $18.2 \%$ & $5.3 \%$ & $10.6 \%$ & $100 \%$ \\
\hline Total & 20 & 67 & 24 & 7 & $\mathrm{I} 4$ & 132 \\
\hline
\end{tabular}

The study also finds that at least $16 \%$ of teachers have purchased new equipment to conduct online classes. That means modernization and technological awareness are increased and improved by the faculty members. Many of the universities of Bangladesh had arranged online training programs for the teachers after the corona pandemic. Technology and network-based interactions between teachers and students are significantly improved through online teachings. Table 3.0 shows that $78 \%$ of teachers agreed \& strongly agreed with this issue. Sixty-three percent of respondents admit that this system creates a chance to work from home now and then.

\section{Policy Recommendation}

Based on result and analysis, the study recommends some policy which can be implemented by three bodies: Owners \& authorities of private universities, University Grants Commission (UGC) and the Government of the People's Republic of Bangladesh. University owners \& authorities should provide necessary logistic supports and financial supports to the teachers. They should arrange effective training programs by the expert to train the teachers for online teaching. Universities must purchase a licensed platform for online teaching. The government should encourage mobile phone companies to reduce the internet costs or ask them to offer special low costs education package for teachers and students as part of corporate social responsibilities. As users claim that the internet networks in rural areas are not satisfactory, the government can force the companies to improve the network at the rural level. The UGC can take initiative to observe the role of the authorities of private universities whether they abide by or not the rules prescribed by the UGC regarding online teaching. Faculty members should adapt themselves to the changing academic system. They should accept the new system and technology easily.

\section{Conclusion}

The study mainly focuses on the views of the faculty members of private universities in conducting online classes during the corona pandemic regarding financial and administrative issues. Study finds some reasons for online classes like financial needs and obligations of the university to pay the salaries and other allowances by collecting tuition fees from the students, to save the academic year of the students, to follow the directives the UGC and Government, etc. The study also finds some significant differences in the uses of technology, internet, and equipment by the teachers before and during the corona pandemic. Online teaching has significant effects on teachers' training, student's punctuality in attending classes, interactions between teachers $\&$ students. It also helps authority in monitoring the classes. Finally, the study recommends some policy guidelines for the University Owners \& authorities, Government, UGC, and the faculty members as well.

The study ignores the views of the administration and the owners of private universities. The study also avoids the students' feedback and reaction to online classes. Therefore, it is a chance for new researchers to do further research in this field.

\section{References}

Akter, A. (2017). Factors to Improve the Quality of Higher Education in the Non Government Universities in Bangladesh. International Journal of Education, Culture and Society, 2(4), I32-I42. https://doi.org/I0.11648/j.ijecs.20170204.15

Daily Jugantor, Bangladesh. (2020). Bangladesh Internet users cross one crore. Retrieved from https://www.jugantor.com/national 
DhakaTribune, Bangladesh. (2020). UGC: Private universities can hold online exams with conditions. Retrieved from https://www.dhakatribune.com/bangladesh/education/2020/05/07/ugc-issues-I4-directives-for-privateuniversities-conducting-online-classes

Gomes, K. (2020). Teachers-students collaboration during Covid-I9. Retrieved from https://tbsnews.net/thoughts/teachersstudents-collaboration-during-covid-19-83I25

Gregory, J., \& Salmon, G. (20I3). Professional development for online university teaching. Distance education, 34(3), $256-270$. https://doi.org/I0.1080/01587919.2013.835771

Islam, M. N. (2015). An Introduction to Research Methods. $3^{\text {rd }}$ Edition. Dhaka, Bangladesh: Mullick \& Brothers

Jasim, M. M. (2020). Private universities in salary shock. Retrieved from https://tbsnews.net/bangladesh/education/privateuniversities-salary-shock-76984

Khan, A. S. (2020). Broadband landscaping in post-COVID-I9 Bangladesh. Retrieved from https://www.thedailystar.net/opinion/news/broadband-landscaping-post-covid-I9-bangladesh-1903I95

Neazy, S. N. (2020). Private Universities Cut Faculty Salaries. Retrieved from https://www.dailysun.com/printversion/details/48069I/Private-Universities-Cut-Faculty-Salaries

UGC, Bangladesh. (2020). Conducting Online Classes, Examinations, and Online Admission of Private Universities During Corona Pandemic. (Circular no. UGC/PU/769(OI)/2018/22I4). Retrieved from www.ugc.gov.bd

Verpoorten, D., Westera, W., \& Specht, M. (20I2). Using reflection triggers while learning in an online course. British Journal of Educational Technology, 43(6), I030-1040. https://doi.org/I0.I I I /j.I467-8535.201 I.01257.x

Appendix

\section{Biography of the Respondents}

\begin{tabular}{|c|c|c|c|c|c|}
\hline \multirow[t]{3}{*}{ OI } & \multicolumn{5}{|l|}{ Name (optional) } \\
\hline & \multicolumn{5}{|l|}{ University (Optional) } \\
\hline & \multicolumn{5}{|l|}{ Mobile no./Email (Optional) } \\
\hline 02 & Rank of Teacher $(\sqrt{ }) \quad$ Professor & Associate Professor & Assistant Professor & Senior Lecturer & Lecturer \\
\hline 03 & Taught Stream $(\sqrt{ })$ & & General & Scie & \\
\hline 04 & Location of the University $(\sqrt{ })$ & Metropol & n City & City & \\
\hline
\end{tabular}

Instructions for the Respondents

\section{Query from the Respondents}

For each of the following statements represent your point of view provided into the box. Please be honest and straight forward to express your opinion and answer, which is confidential also. Use the following scale where it is applicable.

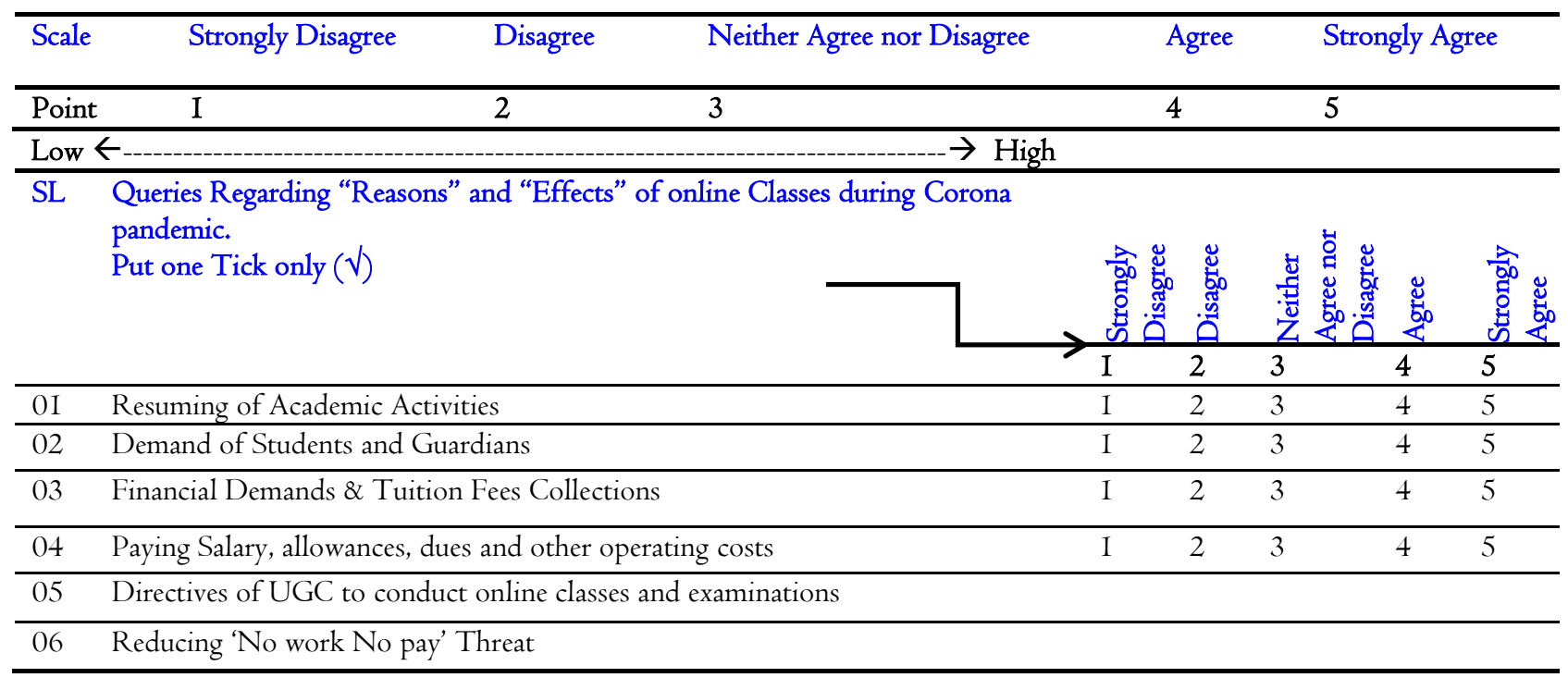




\begin{tabular}{|c|c|c|c|c|c|c|}
\hline 07 & Work from Home Opportunity & $\mathrm{I}$ & 2 & 3 & 4 & 5 \\
\hline 08 & Interactions of Teachers and Students Improved & & & & & \\
\hline 09 & Class monitoring becomes easier by the authority & $\mathrm{I}$ & 2 & 3 & 4 & 5 \\
\hline IO & $\begin{array}{l}\text { Purchasing of New PCs, Laptop, Tablets, or Smart Phones by Teachers for online } \\
\text { classes }\end{array}$ & I & 2 & 3 & 4 & 5 \\
\hline II & Maximum Teachers were well trained on online teaching before corona pandemic & $\mathrm{I}$ & 2 & 3 & 4 & 5 \\
\hline 12 & Teachers were well equipped for online teaching before corona pandemic & $\mathrm{I}$ & 2 & 3 & 4 & 5 \\
\hline 13 & $\begin{array}{l}\text { Maximum university arranged training program for teachers regarding online } \\
\text { training }\end{array}$ & $\mathrm{I}$ & 2 & 3 & 4 & 5 \\
\hline 14 & $\begin{array}{l}\text { Most private universities provided financial support of internet data cost to the } \\
\text { teachers }\end{array}$ & $\mathrm{I}$ & 2 & 3 & 4 & 5 \\
\hline 15 & $\begin{array}{l}\text { Student participations and attendances are not more in online classes than in } \\
\text { regular on-campus classes }\end{array}$ & $\mathrm{I}$ & 2 & 3 & 4 & 5 \\
\hline
\end{tabular}

\section{Copyrights}

Copyright for this article is retained by the author(s), with first publication rights granted to the journal. This is an open-access article distributed under the terms and conditions of the Creative Commons Attribution license (http://creativecommons.org/licenses/by/4.0/). 